\title{
A NEW GROUND DOVE FROIM THE WEST INDIES
}

By Stuart T. Danforth

In a series of 40 Ground Doves in my collection obtained in Puerto Rico, the Virgin Islands and the northern Lesser Antilles, I find that there is a constant difference in the color of the bills of freshly killed specimens. Specimens from Puerto Rico, Culebra and Cayo Norte have the basal two-thirds of the bill bright rose red and the tip black or dusky. Those from St. Croix and the Lesser Antilles have the bill of a uniform dusky color with no trace of red at the base, sometimes with a trace of dull orange-yellow. Specimens from St. Thomas and the British Virgin Islands are intermediate in this respect, the bill being mainly dusky with a small amount of rose red at the base. Since these differences are constant, it seems desirable to regard the Ground Doves inhabiting this area as belonging to two forms. To the bird from Puerto Rico and the Virgin Islands the name Columbigallina passerina portoricensis (Lowe) can be applied, but the bird from the northern Lesser Antilles is apparently left without a name, so I propose to call it

Columbigallina passerina nigrirostris subsp. nov.

Type-Coll. S. T. Danforth No. 1532, adult male, Canada Hill, St. Kitts, B. W. I., June 22, 1935. Collected by S. T. Danforth.

Subspecific characters.-Similar to Columbigallina passerina portoricensis (Lowe), but color of bill entirely dusky, occasionally with a trace of dull orange yellow at the base.

Measurements of type.-Wing 79.0 ; tail 60.6 ; culmen from base 15.7; tarsus 16.8; length (in flesh) 173 ; extent 253.5 millimeters.

Range.-St. Croix and northern Lesser Antilles from St. Martin south probably to Dominica. Specimens examined from St. Croix, St. Martin, St. Eustatius, St. Kitts, Nevis, Barbuda and Antigua.

Remarks.-Although specimens from Guadeloupe and Dominica have not been examined, they are probably referable to this form, as Verrill (Trans. Ct. Acad., 8, 1892, p. 324) remarks that birds from Dominica have a "brown" bill.

Specimens from St. Thomas, St. Jan, and the British Virgin Islands are intermediate, showing much less red at the base of the bill than specimens from Puerto Rico and Culebra, but are best regarded as portoricensis. 
Any differences in plumage and size between the two forms are so slight as not to be worthy of note. The wings of 28 specimens (regardless of sex) of portoricensis measure 76.7-82.8 millimeters (average 79.57) ; those of 12 specimens of nigrirostris measure 74.6-81.4 millimeters (average 78.01).

Material examined:-Columbigallina passerina portoricensis 28 specimens (Puerto Rico 14, including 3 from Caja de Muertos; Culebra 3; Cayo Norte 2; St. Thomas 2; St. Jan 2; Jost van Dyke 1; Tortola 2; Beef Island 1; Virgin Gorda 1). Columbigallina passerina nigrirostris 12 specimens (St. Croix 2; St. Martin 2; St. Eustatius 1; St. Kitts 3; Nevis 2; Barbuda 1; Antigua 1). 